\title{
A NEW RECORD OF BETTA SPLENDENS (ANABANTIFORMES: OSPHRONEMIDAE] FOR THE NORTHEASTERN BRAZIL
}

\author{
UM NOVO REGISTRO DE BETTA SPLENDENS COSPHRONEMIDAEJ PARA O NORDESTE BRASILEIRO
}

\author{
OCURRENCIA DE BETTA SPLENDENSCOSPHRONEMIDAEJ EN AMBIENTES NATURALES DEL NORESTE DE \\ BRASIL
}

Caroline da Silva Oliveira ${ }^{1}$

Felipe Pontieri de Lima²

Diogo Freitas Souza ${ }^{3}$

Ana Maria Peixoto Fontes Vicensotto ${ }^{4}$

André Batista Nobiles

\begin{abstract}
The introduction of exotic species, although harmful to the natural environment, still occurs accidentally, intentionally or as a strategy of biological control. In this work, a specimen of Betta splendens was collected and recorded for Northeastern Brazil, a fish of the family Osphronemidae, originally from Asia. This species has the potential to compete with the native species, causing alterations in the natural community. The record of this species in Brazilian environments and the lack of diagnostic works on this region makes this work of special importance and as an incentive for future investigations.
\end{abstract}

Key words: introduction, exotic species, fish.

\section{Resumo}

A introdução de espécies exóticas, embora prejudicial ao meio ambiente, ainda ocorre acidentalmente, intencionalmente ou como estratégia de controle biológico. Neste trabalho, foi coletado e registrado no Nordeste do Brasil um espécime de Betta splendens, peixe da família Osphronemidae, originário da Ásia. Esta espécie tem potencial para competir com as nativas, causando alterações na comunidade natural.

1 Instituto de Biociências de Botucatu, UNESP - Univ Estadual Paulista “Júlio de Mesquita Filho", Campus Botucatu, Departamento de Zoologia, Laboratório de Ictiologia. 18618-689. SP, Brazil. E-mail: oliveira.caroline.dasilva@gmail.com

2 Ictiológica Consultoria Ambiental ME-LTDA, Rua Primo Paganini, 990 - Casa C, 18.6o8-190, Botucatu - SP, Brazil. E-mail: fpl.limao@hotmail.com

3 Instituto de Biociências de Botucatu, UNESP - Univ Estadual Paulista "Júlio de Mesquita Filho", Campus Botucatu, Departamento de Zoologia, Laboratório de Ictiologia. 18618-689. SP, Brazil. E-mail: souza.d.freitas@gmail.com

4 Instituto de Biociências de Botucatu, UNESP - Univ Estadual Paulista “Júlio de Mesquita Filho", Campus Botucatu, Departamento de Zoologia, Laboratório de Ictiologia. 18618-689. SP, Brazil. E-mail: ana_vicensotto@hotmail.com

5 Ictiológica Consultoria Ambiental ME-LTDA, Rua Primo Paganini, 990 - Casa C, 18.6o8-19o, Botucatu - SP, Brazil. E-mail: andrenobile@hotmail.com 
O registro dessa espécie nos ambientes brasileiros e a falta de trabalhos diagnósticos sobre a situação na região tornam esse estudo de especial importância e como fator de incentivo para futuras investigações.

Palavras chave: introdução, espécie exótica, peixe.

\section{Resumen}

La introducción de especies exóticas, aunque perjudicial para el medio ambiente natural, se sigue produciendo accidental, intencional o como una forma de estrategia de control biológico. En este trabajo, se recoge y queda grabada en el Nordeste de Brasil un ejemplar de Betta splendens, un pez de la familia Osphronemidae, originario de Asia. Esta especie tiene potencial para competir con el nativo, causando alteración en la comunidad natural. El registro de esta especie en ambientes de Brasil y la falta de trabajo de diagnóstico sobre el tipo de situación en la región hace que este trabajo especial importancia y como un factor de empuje para las investigaciones futuras.

Palabras clave: introducción; especie exótica; pez.

\section{INTRODUCTION}

The South American continent holds the richest fish fauna of the planet with 5160 described species, representing $1 / 3$ of the global freshwater species richness (Reis et al., 2016). However, many human actions negatively contribute to the conservation of this region, causing the reduction of native populations to extreme limits (Cowx, 2002).

Among these actions, are the introduction of non-native species, an important cause of disturbance in the ecosystems (Vitousek et al., 1997). Despite this, introductions of non-native species frequently occur in several regions of the World (Vitule et al., 2009; Welcomme, 1989).

In Brazil, most of the fish introductions in freshwater environments occur through aquaculture activities (Azevedo-Santos et al., 2011, Ortega et al., 2015), including fishes and associated organisms (Agostinho et al., 2007; Nobile et al. 2020). However, other human activities have been often recognized as different ways of new introductions (e.g., fishkeeping, sport fishing, etc.) (Azevedo-Santos et al., 2015).

Betta splendens (Regan, 1910) is a member of the family Osphronemidae, a fish native from Asia (Welcomme, 1989), and naturally occurring in poor oxygen swampy environments, such as rice paddies and swamps (Faria et al., 2006). Due to anthropogenic actions, especially aquarium releases, this specie was introduced in Europe (France) in 1874 and in the United States (Goldstein, 2004) in 1910. Currently, the species is widespread throughout the American continent, including Brazil (Welcomme, 1989). In this country, this species is one of the most popular in aquarium trade. Moreover, it has been studied for the biological control of mosquitoes, such as 
Aedes aegypti (Linnaeus, 1762) and Culex quinquefasciatus Say, 1823 (Pamplona et al. 2004).

Recently, B. splendens had four new records reported for two Brazilian states, Ceará and Pernambuco (Leão et al., 2011). However, records of this species in Brazil's natural environments (rivers, lakes, reservoirs) are rare in the literature. In this work, a new record for $B$. splendens is reported from a coastal waterbody of Northeast Brazil.

\section{MATERIAL AND METHODS}

During an analysis of the ichthyological collection of UNESP - Botucatu (LBP -Laboratório de Biologia e Genética de Peixes), an unusual record of occurrence was found for a single specimen of $B$. splendens . According to the data obtained from the batch, the specimen was collected in October 2012 (IBAMA: 13843-1), in Tracunhaém

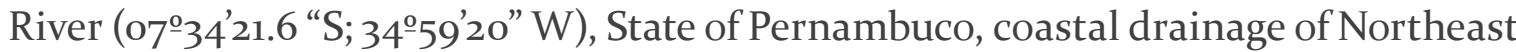
Brazil (Figure 1).

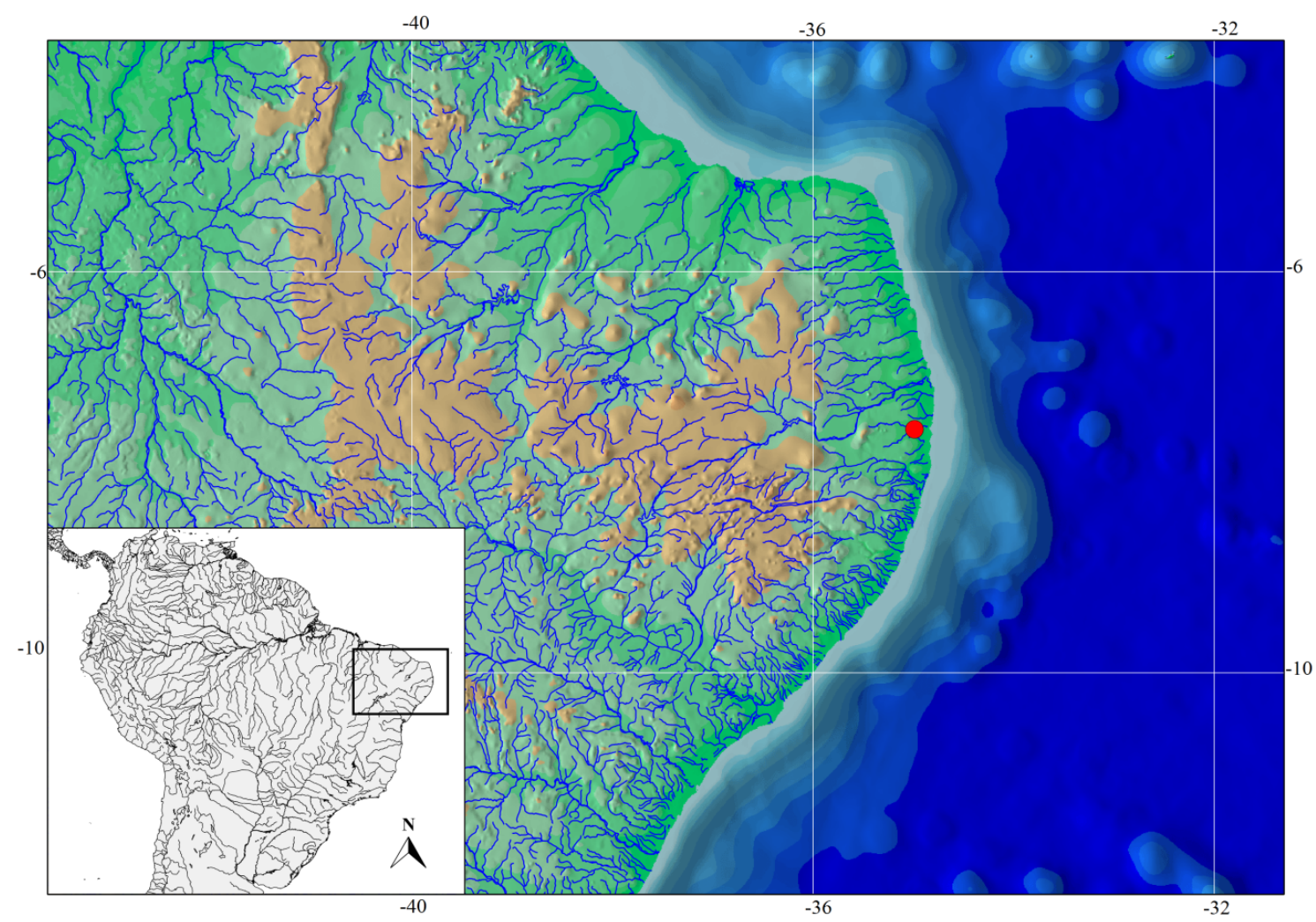

Figure 1. Map indicating the new location of occurrence of Betta splendens in the coastal drainage of Northeastern Brazil. 


\section{RESULTS AND DISCUSSION}

The single adult specimen captured was morphologically identified as a female with $45.13 \mathrm{~mm}$ standard length (Figure 2). The sexual dimorphism in this species is observed from the age of two months and evidenced by the more developed fins of males, which are much larger than the female's in adult specimens. Addditionally, it is noteworthy that in some captive specimens this distinction is made only from the behavior of the male, which appears to be much more aggressive than the female's (Faria et al. 2006)

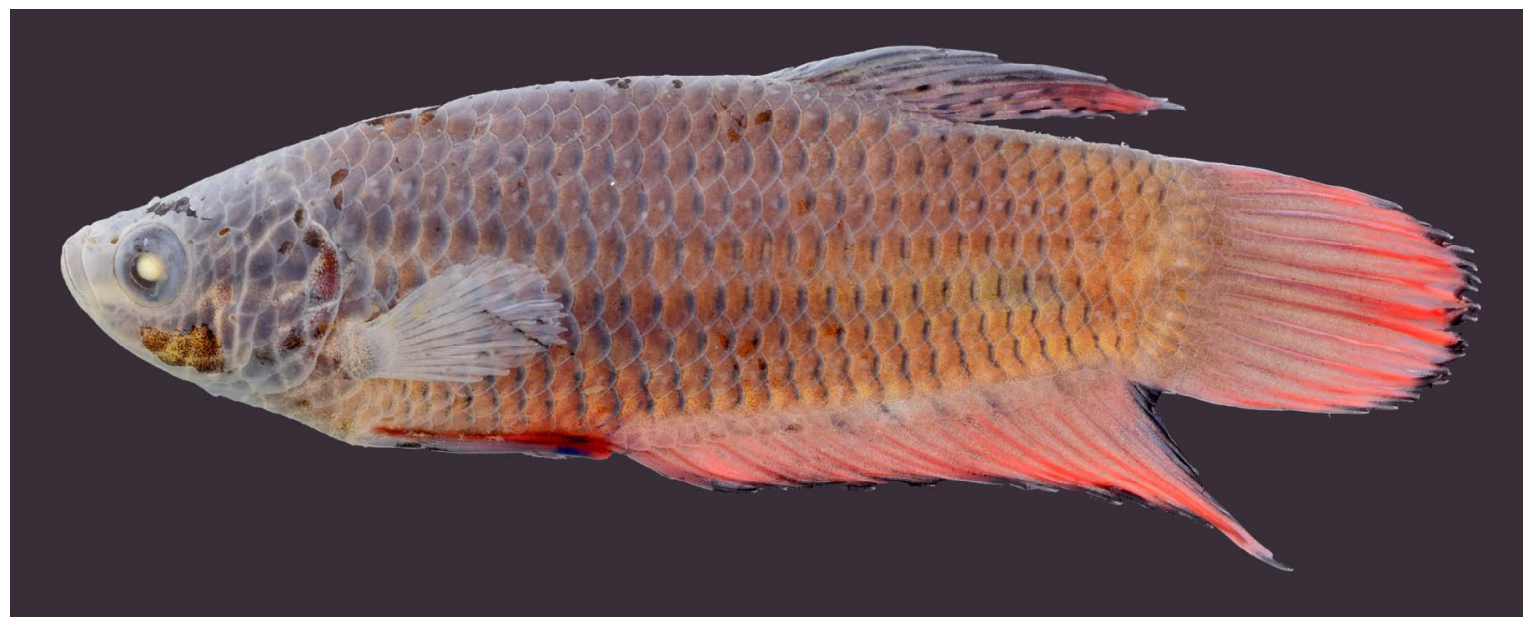

Figure 2. Specimen of Betta splendens caught in the Northeastern coastal region.

Although a new record is reported for the state of Pernambuco, it is impossible to assert if this species is already stablished in this region based on a single specimen. Moreover, there is no evidence of reproduction and/or recruitment for this species in this region (Duggan et al., 2006; Vermeij, 1996). However, there are two hypotheses of how this specimen may have been released in the environment.

In general, there are several ways of introducing a non-native fish species in the continental ecosystems, including aquaculture, fishkeeping, sport fishing, biological control and the use of live baits (Azevedo-Santos et al, 2015; Júlio et al. 2009; Langeani et al. 2007). Still, given the fact that this species is highly explored for different purposes around the world, we suggest here two likely possibilities for their introduction Cavalcanti et all. 2007; Oliveira Lima et all. 2010; Magalhães \& Jacobi, 2013).

Betta splendens is much appreciated in aquarism (Magalhães \& Jacobi, 2013). Therefore, there is the possibility that its introduction has occurred in the region as a result of aquarium dumping. In this sense, several authors point out that the aquarism has become one of the main routes of introduction of non-native fish species due to the easiness of acquiring a wide range of species from all around the world in any 
specialized store, a trend that has gained increasing popularity (Magalhaes \& Jacobi, 2010, 2013; Padilha \& Williams, 2004).

In general, Duggan et al. (2006) argue that the popularity of a species and how often it occurs in aquarium shops can be a determining factor for its subsequent introduction because it acts as a propagule pressure. Thus, there is a clear relationship between widely marketed species (as is the case of $B$. splendens) and its release into the environment.

Another factor that may have caused the introduction of this individual in the natural environment is the use of non-native fish species in the control of populations of mosquitoes, such as Aedes aegypti (Azevedo-Santos et al., 2016). Some species have been introduced in the aquatic environment through this way, as is the case with the upper Paraná river (Langeani et al., 2007). Betta splendens has been effectively employed to combating A. aegypti (e.g., Pamplona et al., 2004) and has been reported as a potential species in the fight against mosquitoes (Trigueiro, 2015).

\section{CONCLUSION}

This study expands the area of occurrence of the species Betta splendens in Brazil, as well as highlights the potential of its introduction as a consequence of the aquarism and of its employment in the biological control of mosquitoes.

\section{ACKNOWLEDGMENT}

The authors thank the curator of the ichthyological collection of the Laboratorio de Biologia e Genética de Peixes, Dr. Claudio Oliveira, by providing access to the collected specimen and Ricardo Britski and Raquel Siccha-Ramirez for collecting it. We also thank CNPq and CAPES for granting scholarships of master, doctoral and postdoctoral degrees to the authors.

\section{REFERENCES}

Agostinho, A. A., Gomes, L. C. \& Pelicice, F. M. (2007). Ecologia e Manejo de Recursos Pesqueiros em Reservatórios do Brasil. Eduem, Maringá, 501 p.

Azevedo-Santos Valter Monteiro de, Rigolin-Sá Odila, Pelicice Fernando Mayer. 2011. Growing, losing or introducing? Cage aquaculture as a vector for the introduction of non-native fish in Furnas Reservoir, Minas Gerais, Brazil. Neotropical. ichthyologi. 9( 4 ): 915-919. 
Azevedo-Santos, V. M., Pelicice, F. M., Lima-Junior, D. P., Magalhães, A. L. B., Orsi, M. L., Vitule, J. R. S. \& Agostinho A. A. (2015). How to avoid fish introductions in Brazil: education and information as alternatives. Natureza $\mathcal{E}$ Conservação, 13, 123-132.

Azevedo-Santos, V. M., Vitule, J. R. S., García-Berthou E., Pelicice, F.M. \& Simberloff, D. (2016). Misguided strategy for mosquito control. Science, 351(6274), 675.

Cavalcanti, L.P.G; Pontes R.J.S; Regazzi, N.C.F; Júnior F.J.P; Frutuoso, R.L; Sousa, E.P; Filho, F.F.D; Lima, J.W.O; (2007). Efficacy of fish as predators of Aedes aegypti larvae, under laboratory conditions. Rev Saúde Pública; 41(4); 1-6.

Collares-Pereira, M. J., Cowx, I. G. \& Coelho, M. M. (2002). Conservation offreshwater fishes: options for the future. Fishing News Books, Oxford. 472p.

Cowx, I. G. (2002). Analysis of threats to freshwater fish conservation: past and present challenges. In M. J. Collares-Pereira, I. G. Cows \& M.M. Coelho (Eds.) Conservation of Freshwater Fishes: Options for the Future (pp. 201-220). Oxford.

Trigueiro, P. 2015. Mosquitos de Zika e Dengue Viram Comida de Peixe no Interior de Pernambuco. http://curiosamente.diariodepernambuco.com.br/project/zika-edengue-viram-comida-de-peixe-no-interior-de-pernambuco/; last visit: 25.VII.2016.

Duggan, I. C., Rixon, C.A. M. \& Macisaac, H. J. (2006). Popularity and propagule pressure: determinants of introduction and establishment of aquarium fish. Biological Invasions, 8(2), 377-382.

Faria, P. M. C., Crepaldi, V. D., Teixeira, E. A., Ribeiro, L. P., Souza, A. B., Carvalho, D. C., Melo, D. C. \& Saliba, E. O. S. (2006). Criação, manejo e reprodução do peixe Betta splendens (Regan 1910). Revista Brasileira de Reprodução Animal, Belo Horizonte, 30(3/4), 134-149.

Goldstein, R. J. (2004). The Betta Handbook. Hauppauge, Barron's Pet Handbooks, New York. 176 p.

Langeani, F., Castro, R. M. C., Oyakawa, O. T., Shibatta, O. A., Pavanelli, C. S. \& Casatti, L. (2007). Ichthyofauna diversity of the upper rio Paraná: present composition and future perspectives. Biota Neotropica, 7(3), 181-197.

Leão, T. C. C., Almeida, W. R., Dechoum, M. S. \& Ziller, S. R. 2011. Espécies Exóticas Invasoras no Nordeste do Brasil: Contextualização, Manejo e Políticas Públicas. Centro de Pesquisas Ambientais do Nordeste e Instituto Hórus de Desenvolvimento e Conservação Ambiental. Recife, PE. 
Magalhães, A. L. B. D. \& Jacobi C. M. (2010). E-commerce of freshwater aquarium fishes: potential disseminator of exotic species in Brazil. Acta Scientiarum - Biological Sciences, 32, 243-248.

Magalhães, A. L. B. D. \& Jacobi C. M. (2013). Invasion risks posed by ornamental freshwater fish trade to southeastern Brazilian rivers. Neotropical Ichthyology, 11(2), 433-441.

Nobile, A.B., Cunico, A.M., Vitule, J.R.S., Queiroz, J., Vidotto-Magnoni, A.P., Garcia, D.A.Z., Orsi, M.L., Lima, F.P., Acosta, A.A., da Silva, R.J., do Prado, F.D., Porto-Foresti, F., Brandão, H., Foresti, F., Oliveira, C., Ramos, I.P., 2019. Status and recommendations for sustainable freshwater aquaculture in Brazil. Rev. Aquac. raq.12393. https://doi. org/10.1111/raq.12393

Ojasti, J. (2001). Estudio sobre el estado actual de las especies exóticas. CaracasVenezuela.

Oliveira Lima, J.W., De Góes Cavalcanti, L.P., Pontes, R.J.S., Heukelbach, J., 2010. Survival of Betta splendens fish (Regan, 1910) in domestic water containers and its effectiveness in controlling Aedes aegypti larvae (Linnaeus, 1762) in Northeast Brazil. Trop. Med. Int. Heal. 15, 1525-1532. https://doi.org/10.1111/j.1365-3156.2010.02658.x

Ortega, J. C. G., Júlio, H. F., Gomes, L. C. \& Agostinho, A. A. (2015). Fish farming as the main driver of fish introductions in Neotropical reservoirs. Hydrobiologia 746, $147-158$,

Padilha, D. K. \& Williams, S. L. (2004). Beyond ballast water: aquarium and ornamental trades as sources of invasive species in aquatic ecosystems. Front. Ecol. Environ. 2(3), 131-138.

Pamplona, L. D. G. C., Lima, J. W. D. O., Cunha, J. C. D. L. \& Santana, E. W. D. P. (2004). Evaluation of the impact on Aedes aegypti infestation in cement tanks of the municipal district of Canindé, Ceará, Brazil after using the Betta splendens fish as an alternative biological control. Revista da Sociedade Brasileira de Medicina Tropical, $37(5), 400-404$.

Pelicice, F.M., Agostinho, A.A., 2009. Fish fauna destruction after the introduction of a non-native predator (Cichla kelberi) in a Neotropical reservoir. Biol. Invasions 11, 1789-1801. https://doi.org/10.1007/s10530-008-9358-3

Reis R. E., Albert J. S., Di Dario F., Mincarone M. M., Petry P. \& Rocha L. A.. 2016. Fish biodiversity and conservation in South America. Journal of Fish Biology, 89(1), 12-47. 
Vermeij, G. J. 1996. An agenda for invasion biology. Biological conservation, 78(1), 3-9.

Vitousek, P. M., Mooney, H. A., Lubchenco, J. \& Melillo, J. M. (1997). Human domination of Earth's ecosystems. Science. 277, 494-499.

Vitule, J. R. S.; Freire, C. A. \& Simberloff, D. (2009): Introduction of non-native freshwater fish can certainly be bad. Fish Fish. 10, 98-108.

Welcomme, R. L. 1989. International Introductions of Inland Aquatic Species. FAO, Rome. 318 p. 